\title{
THE INCIDENCE OF PENICILLIN-RESISTANT STAPHYLOCOCCI IN A SEMI-CLOSED COMMUNITY
}

\author{
BY \\ B. A. THOMPSON AND HERTA SCHWABACHER \\ From the Group Laboratory, Watford
}

(RECEIVED FOR PUBLICATION OCTOBER 20, 1950)

Barber and Rozwadowska-Dowzenko (1948) recorded that naturally resistant penicillinase-producing staphylococci found within hospital communities had increased in the previous successive three years from $14 \%$ to $38 \%$ and then to $59 \%$. Forbes (1949) isolated resistant staphylococci from 23 out of 50 nurses. Martin and Whitehead (1949) examined the nose, throat, saliva, and skin of 50 medical students and laboratory workers and found the carrier rate of resistant staphylococci to be $19.4 \%$ in this semi-closed community.

In view of the increasing incidence of resistant staphylococci in closed communities, it was decided to investigate the carrier state in another type of semiclosed community. The community chosen was a boys' grammar school. A constant set of 30 16-year-old boys occupying the same classroom had both anterior nares swabbed for the isolation of staphylococci. They were swabbed monthly over a period of 12 months.

The tube coagulase test was used to recognize Staph. pyogenes; strains were regarded as penicillin-resistant if their growth was inhibited by 0.25 to 0.5 units penicillin per ml. All resistant strains produced sufficient penicillinase after 18 hours' incubation to neutralize 30 units penicillin per $\mathrm{ml}$.

\section{Technique}

The swab taken from both anterior nares was plated on to horse blood $2 \%$ agar (Table.I A) on to $7.5 \%$ salt agar in the manner described by Maitland and Martyn in 1948 (Table I B), inoculated into nutrient broth (Table I C), and into broth containing 20 units penicillin per $\mathrm{ml}$.

The blood and salt agar plates were incubated aerobically for 18 hours: the nutrient broths were incubated anaerobically for 18 hours and then subcultured on to blood agar plates for overnight aerobic incubation. The penicillin broths were incubated aerobically for 18 hours; no staphylococci were found in the tubes from this series, those with growth being found, by Gram stain, to contain Gram-negative bacilli.

All plates were left on the bench at room temperature for 24 hours in order to increase colonial pigmentation. Colonies believed to be Staph. pyogenes were tested for coagulase in $10 \%$ plasma broth to which heparin was added giving $2.5 \%$ Toronto units per ml. (Harper and Conway, 1948). All strains yielding clot within 18 hours were streaked on to penicillin ditch plates, each ditch containing 10 units penicillin per $\mathrm{ml}$. After incubation the organisms growing up to the ditch were considered to be resistant 
TABLE I

Summary of All Staphylococci Isolated over 12 MoNTHS from the SAME Group of 30 SCHOOLBOYS

\begin{tabular}{|c|c|c|c|c|c|c|c|c|c|c|}
\hline \multirow[b]{2}{*}{$\begin{array}{l}\text { Month } \\
\text { (1949) }\end{array}$} & \multicolumn{3}{|c|}{ A } & \multicolumn{3}{|c|}{ B } & \multicolumn{3}{|c|}{$\mathrm{C}$} & \multirow[b]{2}{*}{$\begin{array}{l}\text { No. of } \\
\text { Carriers of } \\
\text { Resistant } \\
\text { Staphy- } \\
\text { lococci }\end{array}$} \\
\hline & $\begin{array}{l}\text { No. of } \\
\text { Colonies } \\
\text { Picked }\end{array}$ & $\begin{array}{c}\text { Coagu- } \\
\text { lase } \\
\text { Positive }\end{array}$ & $\begin{array}{l}S \\
\text { or } \\
R\end{array}$ & $\begin{array}{l}\text { No. of } \\
\text { Colonies } \\
\text { Picked }\end{array}$ & $\begin{array}{c}\text { Coagu- } \\
\text { lase } \\
\text { Positive }\end{array}$ & $\begin{array}{l}\mathbf{S} \\
\text { or } \\
\mathbf{R}\end{array}$ & $\begin{array}{c}\text { No. of } \\
\text { Colonies } \\
\text { Picked }\end{array}$ & $\begin{array}{c}\text { Coagu- } \\
\text { lase } \\
\text { Positive }\end{array}$ & $\begin{array}{l}\mathbf{S} \\
\text { or } \\
\mathbf{R}\end{array}$ & \\
\hline Feb. & 33 & 14 & $14 \mathrm{~S}$ & 29 & 16 & $\begin{array}{r}15 \mathrm{~S} \\
1 \mathrm{R}\end{array}$ & 11 & 7 & $7 \mathrm{~S}$ & 6 \\
\hline Mar. & 32 & 11 & $\begin{array}{r}10 \mathrm{~S} \\
1 \mathrm{R}\end{array}$ & 33 & 14 & $14 \mathrm{~S}$ & 14 & 5 & $5 \mathrm{~S}$ & 5 \\
\hline Apr. & 41 & 13 & $13 \mathrm{~S}$ & 40 & 17 & $\begin{array}{r}15 \mathrm{~S} \\
2 \mathrm{R}\end{array}$ & 11 & 11 & $\begin{array}{r}10 \mathrm{~S} \\
1 \mathrm{R}\end{array}$ & 6,15 \\
\hline May & 37 & 11 & $\begin{array}{r}10 \mathrm{~S} \\
1 \mathrm{R} \\
\end{array}$ & 31 & 15 & $\begin{array}{r}14 \mathrm{~S} \\
1 \mathrm{R}\end{array}$ & 10 & 9 & $\begin{array}{l}8 \mathrm{~S} \\
1 \mathrm{R}\end{array}$ & 15 \\
\hline June & 41 & 16 & $\begin{array}{r}15 \mathrm{~S} \\
1 \mathrm{R}\end{array}$ & 44 & 16 & $\begin{array}{r}14 \mathrm{~S} \\
2 \mathrm{R}\end{array}$ & 16 & 13 & $\begin{array}{r}12 \mathrm{~S} \\
1 \mathrm{R}\end{array}$ & 15,19 \\
\hline July & 40 & 13 & $\begin{array}{r}11 \mathrm{~S} \\
2 \mathrm{R}\end{array}$ & 44 & 17 & $\begin{array}{r}14 \mathrm{~S} \\
3 \mathrm{R}\end{array}$ & 16 & 13 & $\begin{aligned} 11 \mathrm{~S} \\
2 \mathrm{R}\end{aligned}$ & $6,15,19$ \\
\hline Sept. & 36 & 12 & $12 \mathrm{~S}$ & 30 & 9 & $\begin{array}{l}8 \mathrm{~S} \\
1 \mathrm{R}\end{array}$ & 11 & 6 & $\begin{array}{l}4 \mathrm{~S} \\
2 \mathrm{R}\end{array}$ & 6,15 \\
\hline Oct. & 35 & 12 & $\begin{array}{r}10 \mathrm{~S} \\
2 \mathrm{R}\end{array}$ & 24 & 13 & $\begin{array}{r}10 \mathrm{~S} \\
3 \mathrm{R}\end{array}$ & 6 & 5 & $\begin{array}{l}3 \mathrm{~S} \\
2 \mathrm{R}\end{array}$ & $4,10,19$ \\
\hline Nov. & 30 & 8 & $8 S$ & 26 & 8 & $8 \mathrm{~S}$ & 4 & 3 & $3 \mathrm{~S}$ & None \\
\hline Dec. & 41 & 16 & $16 \mathrm{~S}$ & 27 & 15 & $15 \mathrm{~S}$ & 5 & 4 & $4 \mathrm{~S}$ & None \\
\hline Jan. 1950 & 32 & 10 & $10 \mathrm{~S}$ & 18 & 9 & $9 \mathrm{~S}$ & 2 & 1 & $1 \mathrm{~S}$ & None \\
\hline Feb. & 31 & 9 & $9 \mathrm{~S}$ & 14 & 6 & $\begin{array}{l}5 \mathrm{~S} \\
1 \mathrm{R}\end{array}$ & 2 & 1 & $1 \mathrm{~S}$ & 19 \\
\hline Total & 429 & 145 & $\begin{array}{r}138 \mathrm{~S} \\
7 \mathrm{R}\end{array}$ & 360 & 155 & $\begin{array}{r}141 \mathrm{~S} \\
14 \mathrm{R}\end{array}$ & 108 & 78 & $\begin{array}{r}69 \mathrm{~S} \\
9 \mathrm{R}\end{array}$ & \\
\hline
\end{tabular}

A $=$ Swabs direct on blood $2 \%$ agar plate. $\quad B=$ Swabs in $7.5 \%$ salt agar. $\mathbf{C}=$ Swabs in nutrient broth on to blood $2 \%$ agar plate. $\mathrm{S}=$ Sensitive to penicillin. $\mathrm{R}=$ Resistant to penicillin.

strains, and were tested for penicillinase production by their power to neutralize 30 units penicillin (Cruickshank, Squire, and Topley, 1948). The fluid broth culture was tested for complete penicillin neutralization on a staphylococcal pour-plate as described by Barber (1947).

The minimal bactericidal concentration of penicillin of these strains -were determined, and sub-cultures were submitted to Dr. R. E. O. Williams for the determination and interpretation of the phage types. 


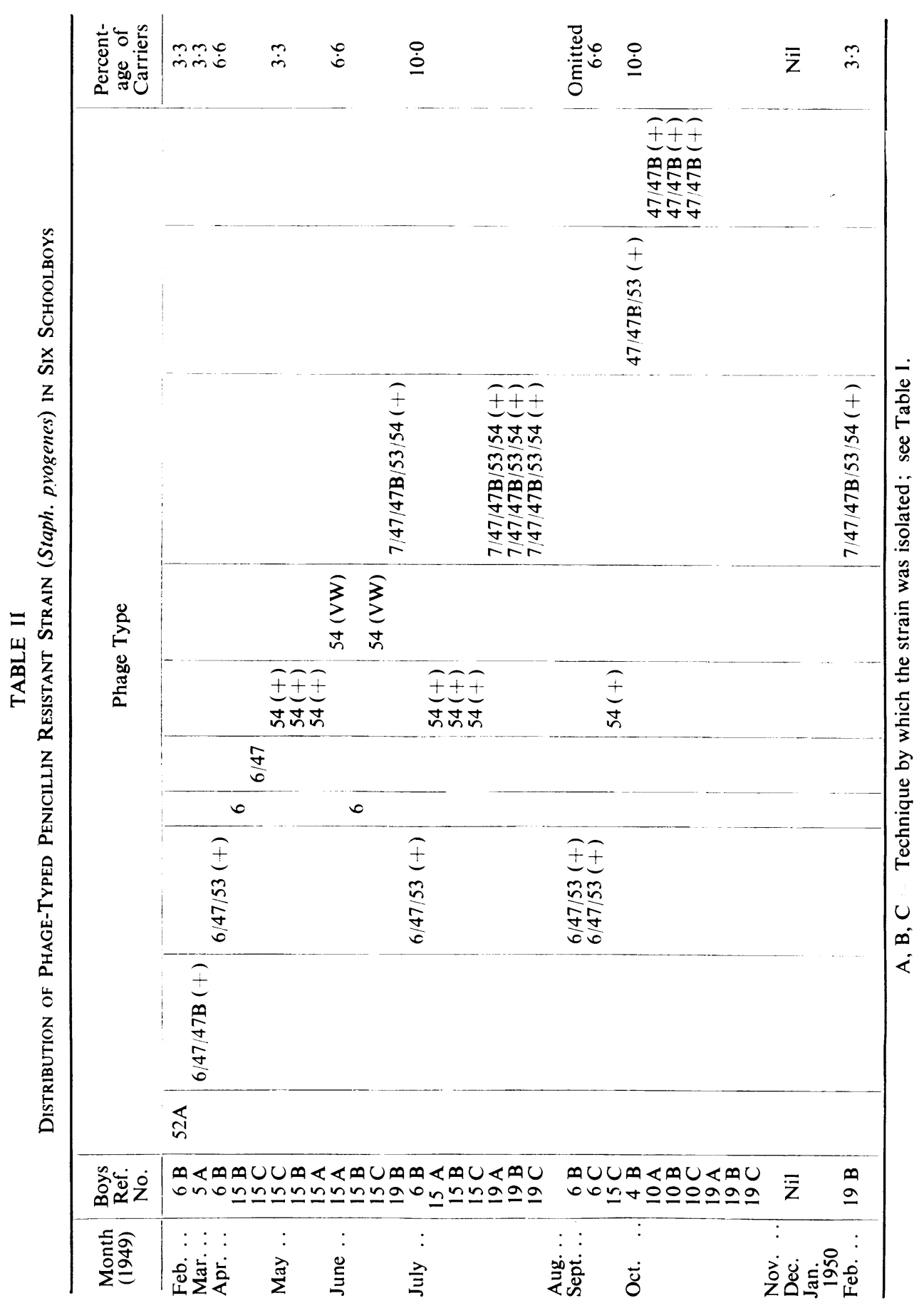




\section{Results}

From Table $\mathrm{I}$ it can be seen that resistant penicillinase-producing staphylococci were isolated twice as often from the salt agar plates (B) compared with direct plating on to blood agar plates (A), and that preliminary broth inoculation (C) was slightly preferable to direct blood agar plating. Despite the fact that all resistant staphylococci isolated from $\mathrm{A}, \mathrm{B}$, and $\mathrm{C}$ neutralized 30 units of penicillin, none of these strains were recovered from direct inoculation into 20 units penicillin per ml. broth. All the resistant strains produced penicillinase.

On one occasion only was a resistant strain recovered from a blood agar plate (A) and not recovered by techniques $\mathrm{B}$ or $\mathrm{C}$.

Table II enumerates the 10 different phage types isolated throughout the 12 months and their distribution between the boys.

There is no evidence of cross-infection between the boys, for at no time was an identical strain isolated from more than one individual.

Out of the 30 boys, a total of six carried resistant staphylococci at varying periods during the year. One boy, No. 6, was a carrier in February, April, July, and September: his strains in the latter three months of the year were identical but different from that found in February. Boy No. 15 carried one strain in April and June, another strain in May, July, and September, and two further distinct organisms in April and May, that is, he carried four varying phage types. Boy No. 19 carried one strain in June, July, and October, 1949, and February, 1950. Unrelated types of staphylococci were isolated once only from boys Nos. 4, 5, 10. On no occasion were there more than three carriers at a time.

None of the boys had septic lesions, nor, so far as could be ascertained, had they been in contact with staphylococcal infections in their homes.

\section{Discussion}

In a semi-closed community of 30 schoolboys, who were confined together for not less than six hours a day for five days a week, no evidence of cross-infection with Staph. pyogenes was obtained from nasal swabs taken at monthly intervals. Had the sampling interval been shorter it is possible that identical strains might have been found in a number of boys. It is evident that there is little likelihood of cross-infection in institutions which did not deal with sickness. In hospitals, where we know cross-infection prevails, Forbes (1949) found $12.5 \%$ resistant staphylococci in an open community from clinical sources of out-patients and $68.4 \%$ in in-patients. The resistant staphylococcal carriers were five times more common in in-patients than in out-patients.

\section{Summary}

A description is given of the isolation of resistant staphylococci from the nares of 30 schoolboys.

Ten different phage types were isolated from six boys.

There was no evidence of cross-infection. At no time throughout the 12 months did any one type of staphylococcus appear in more than one boy.

The highest carrier rate at any one time was $10 \%$.

We should like to thank Dr. R. E. O. Williams for his help in determining and interpreting the phage types. 


\section{REFERENCES}

Barber, M. (1947). J. Path. Bact., 59, 373.

and Rozwadowska-Dowzenko, M. (1948). Lancet, 2, 641

Cruickshank, C. N. D., Squire, J. R., and Topley, E. (1948). Ibid., 2, 989.

Forbes, G. B. (1949). Brit. med. J., 2, 569.

Harper, E. M., and Conway, N. S. (1948). J. Path. Bart., 60, 247.

Maitland, H. B., and Martyn, G. (1948). Ibid., 60, 553.

Martin, T. D. M., and Whitehead, J. E. M. (1949). Brit. med. J., 1, 173. 